УДК 159.913:364-47(378)

DOI https://doi.org/10.26661/2310-4368/2021-4-1

\title{
ДОЦІЛЬНІСТЬ ЗАСНУВАННЯ ГУРТКА 3 ОХОРОНИ ПСИХІЧНОГО ЗДОРОВ'Я НА БАЗІ ВИЩИХ НАВЧАЛЬНИХ ЗАКЛАДІВ ТА ЇХ МОЖЛИВОСТІ
}

\author{
Бергхауер-Олас Е. Л. \\ доктор філософії (Ph. D.), \\ дочент кафедри педагогіки та психології \\ Закарпатський угорський інститут імені Ференца Ракоиі II \\ пл. Кошута, 6, Берегово, Закарпатська область, Україна \\ orcid.org/0000-0002-1576-0286 \\ berghauer.olasz.emoke@kmf.org.ua
}

\begin{abstract}
Ключові слова: проєкт $з$ охорони психічного здоров'я, психологічний гурток, управління стресовими ситуачіями, взаємозв'язки культури міжсособистісних стосунків.
\end{abstract}

Теоретична частина цієї публікації резюмує погляди дослідників та теорії, які стосуються центральної теми дослідження й опубліковані в міжнародній науковій літературі. У дослідженні проведений аналіз стратегій адаптації та подолання труднощів у новому середовищі, а також список профілактичних варіантів, що розроблені на основі програми гуртків з охорони психічного здоров'я, які покращують якість повсякденного життя представників молодого покоління та сприяють підтримці їхнього психологічного здоров'я. Окрім переживання кризи ідентичності, молодь у період вступу до коледжу й університету стикається із труднощами, що виникають у зв'язку з переживанням психологічного комфорту через розлуку зі своїм звичним побутом, домочадцями. Проведені дослідження покликані оцінити рівень задоволеності молоді власним життям та впливу пережитого досвіду та взаємин на формування особистості. Насправді ці соціальні ресурси допомагають їм адаптуватися до нових ситуацій та впоратися зі стресом. Суспільство є своєрідною базою безпеки для підлітка [9].

У процесі своєї професійної діяльності ми стикаємося 3 тим, що щоденний стрес у студентів практично неминучий. Існує безліч можливостей для організації різних профілактичних заходів, які дають змогу навчитися виробляти ефективні стратегії подолання труднощів, які дозволять уникнути вкорінення шкідливих форм поведінки. Насамперед дослідження фокусується на компоненті, який характеризує здатність спільноти до утримання молоді в тому чи іншому середовищі. Люди істоти соціальні, а у зв'язку із припущенням, що суспільство вважається безпечним середовищем для підлітків, нам необхідно забезпечити представникам молодого покоління можливості для пошуку нових перспектив. Запуск проєкту з охорони психічного здоров'я в конкретному вищому навчальному закладі - це новаторська ініціатива, основною метою якої є підвищення обізнаності учасників навчального процесу щодо важливості підтримки психічного здоров'я. Розкриття етапів проєкту 3 охорони психічного здоров'я та результати попереднього SMART-аналізу яскраво демонструють запропоновані можливості. 


\title{
MENTAL HYGIENE SUPPORT GROUP'S OPPORTUNITIES IN HIGHER EDUCATION
}

\author{
Berghauer-Olasz E. L. \\ Doctor of Philosophy, \\ Associate Professor at the Department of Pedagogy and Psychology \\ Ferenc Rákóczi II Transcarpathian Hungarian College of Higher Education \\ Kossuth square, 6, Berehovo, Transcarpathian region, Ukraine \\ orcid.org/0000-0002-1576-0286 \\ berghauer.olasz.emoke@kmf.org.ua
}

Key words: mental hygiene project, support group, stress management, community, conjoint culture.
The theoretical part of this publication deals with those views and theories that are traceable to the central theme in international specialized literature. The study introduces adaptation to the new environment, analyses coping strategies, lists those preventive opportunities offered by support communities and groups that contribute to the improvement of youngsters' everyday life, as well as to their keeping fit. Side by side with experiencing identity crisis, entering an institute or university, youngsters have to face the difficulties of leaving home. Social life, the presence of friends, their support, as well as family and parent bonds are of key importance for teenagers. Numerous studies support the influence of previous experience and relations on the satisfaction of the youngsters with their own life. In fact, these resources offer help in adaptation to new situations, as well as in coping with stress. Community forms a kind of security basis for the teenagers [9].

In the course of practising our profession we experience that everyday stress is almost inevitable for students. There are numerous opportunities to organize prevention programmes of various kind to enable the mastery of efficient coping strategies, thus preventing the preservation of youngsters' detrimental behaviour. Basically, this study analyses the component that emphasizes the community's retaining power. As far as humans are social beings, the community offers a kind of security basis for teenagers offering them opportunities that open up new perspectives. Launching a mental hygiene project in the given educational institution is an innovative initiative that is aimed at attracting people's attention to the significance of preserving mental health. Introduction of the mental hygiene project steps, as well as the example of the previous SMART analysis perfectly demonstrates the available opportunities.
Постановка проблеми. Окрім труднощів інтеграції, перед студентами вищих навчальних закладів стоїть величезне завдання - навчитися адаптуватися до системи вищої освіти та відповідати всім академічним вимогам, що, як показує досвід, часто призводить до раннього відсіву. Студентам важко впоратися зі стресом, що виникає у процесі навчання, під час та перед написанням контрольних, модульних робіт, у зв'язку з перевтомою на заняттях, не можуть зосередитися на парах і мають проблеми 3 концентрацією уваги. Окрім стресів та напруги, пов' язаних з екзаменаційним періодом, їм також доводиться справлятися із сімейними обставинами, підгрунтям виникнення яких здебільшого є волевиявлення почуттів приналежності до суспільства. Результати досліджень потреб студентів, що проводилися раніше [4], вказують на те, що у студентів ще залишився інтерес до навчання, але під час роботи 3 ними необхідно застосовувати інші педагогічні методи. Студентам не вистачає спільного «гніздечка», де вони могли б збиратися щотижня для обговорення тем, які актуальні для їхнього віку і які не мали можливості обговорити вдома (управління стресом, людські стосунки, сімейні обставини, взаємини, соціальна поведінка). Респонденти виявили бажання подивитися фільм на цю тему 3 подальшим обговоренням побаченого, а також взяти участь в іграх та у виконанні вправ, які могли б допомогти в подоланні повсякденних труднощів. 
Основною ичільовою аудиторією проєкту, що реалізується на базі вищих навчальних закладів, мають стати передусім студенти, які навчаються на першому та другому курсах, саме для них має організуватися гурток 3 підтримки психічного здоров'я. Мета проєкту 3 охорони психічного здоров'я - надати студентам можливості для емоційного розкріпачення та поповнення організму новими силами, що дозволить їм розібратися у своїх відносинах. Особливо важливо відзначити, що гурток, який працює на постійній та регулярній основі, може стати першим кроком на шляху до створення інституту сприяння здоров'я, діяльність якого підтримує описану вище концепцію.

Мета. Метою публікації є популяризація перспективи створення вищої інстанції 3 охорони психічного здоров'я. Результати SMART-аналізу демонструють можливості психологічних гуртків з урахуванням потреб вищого навчального закладу.

Окрім переживання кризи ідентичності, молодь у період вступу до коледжу й університету стикається із труднощами, що виникають у зв'язку $з$ тим, що абітурієнтам складно вийти із зони комфорту і розлучитися зі своїми домочадцями. У психологічній літературі існують думки, що від’їзд із дому може викликати в людини симптоми, що нагадують реакцію горя. 3. Фрейд у визначенні терміна «горе» посилається на відповідні теорії, але більш чіткі паралелі із втратою місця та роботою над горем, що виникає внаслідок втрати близьких для індивіда людей, проводить Фріда Фромм-Рейчман у своїх психодинамічних теоріях, висунутих у 1960-х рр. На їі переконання, втрата важливого для людини місця призводить до появи відчуття особистісної неперервності [10].

Результати дослідження, проведені в галузі енвайронментальної психологї, вказують на емоційну прив'язаність людей до свого безпосереднього оточення, до свого будинку, а також на те, що у випадках, коли індивід покидає цей простір, він виходить 3 арени, де він відчуває себе в безпеці та впевненим у собі. Чавла (1992 р.) простежив закономірності прив'язаності людини до конкретного місця, починаючи 3 дитинства і закінчуючи підлітковим віком. У процесі дослідження вдалося 3'ясувати, що дитина щаслива тоді, коли перебуває в місці, де вона почувається як у себе вдома, коли ж вона залишає це місце, у неї проявляються симптоми дистресу. У своїх спостереженнях він виявив тісний зв'язок між соціалізацією та прихильністю до місця, назвавши їх такими, що доповнюють одна одну. Аналогічні міркування можна знайти в роботі Г. Маркуса (1992 р.) щодо того, що емоційний зв'язок дитини із довкіллям має вирішальний вплив на подальший вибір місця проживання та ii облаштування помешкання в дорослому житті. Місце - це, по суті, особистий простір, який сформувався внаслідок інтеракції 3 навколишнім середовищем на основі пережитих соціальних відносин. У формуванні духовної приналежності до певного місця велику роль відіграють пережиті події, що відбулися в оточенні людини, колективний досвід, пов'язаний із життєдайною силою цього місця, та сформовані у процесі спільного обговорення тієї чи іншої ситуації думки [8]. У своєму дослідженні Горват докладно аналізує доведену тезу про те, що покидання як первинної, так і вторинної території, іiі фактична чи психологічна руйнація, провокує горе, яке має схожість із горем, спричиненим втратою близьких людей. У результаті дослідження процесу подолання горя, пов'язаного з покиданням домівки, він розробив триступеневу модель. Перша стадія характеризується неприйняттям і невизнанням, друга - стадія усвідомлення, на якій можуть спостерігатися як ознаки прив'язаності до покинутого місця, так і неприйняття ситуації загалом. На третій стадії переживання втрати інтегруються в особистість. Аналогічні результати спостерігалися в дослідженнях зі студентами, які навчалися далеко від свого дому. Після переривання тісного міжособистісного контакту з однолітками та зміни звичної обстановки, які відігравали ключову роль у житті студентів, у досліджуваної групи осіб відмічалися значні індивідуальні відмінності в подоланні горя, його тяжкості та наявності стадій переживання втрати [10].

3 подібними почуттями переступають поріг нашого інституту студенти, більшість із яких після заселення до гуртожитків мають можливість іздити додому лише раз на тиждень. Важливо, що нові простори можуть набути такого ж значення, як місця, згадані в наведеному вище контексті. Сформоване сприйняття якості нового середовища, простору та пристосованість до його умов змінюються залежно від ступеня впливу нового середовища на досягнення поставлених і формування подальших дій [8].

Дослідники розробили низку психологічних моделей для вивчення й уточнення поняття «копінг». У працях 3. Фрейда наведено відомості про те, що завдання Его - сприймати загрози із зовнішнього світу i, у разі нездатності впоратися 3 ними, запускати захисні механізми. Активізація захисних механізмів насправді $є$ наслідком неспроможності справлятися зі стресом чи ситуацією [6]. Поняття копінгу вперше згадується у працях його дочки Ганни Фрейд (1944р.), де акцентовано увагу на тому, що Его здатне впоратися із проблемами іншими способами. Серед аналітиків найбільш глибокий аналіз концепції копінгу був проведений Н. Хааном (1977р.), який 
дослідив розбіжності між визначеннями «копінг» та «захист». На його думку, копінг - це позитивно заряджений процес, що зважає на мету та вибір людини, а захистом дослідник називає невротичний маневр Его. Побутує думка, згідно з якою поняття копінгу трактується 3 урахуванням особистісних особливостей людини. Згідно із цією моделлю, спосіб подолання труднощів, копінг, можна сприймати як стійку рису особистості. Протягом життя в людини формуються захисні маневри та стратегії подолання стресу, які застосовуються на практиці в разі виникнення непередбачуваної ситуація. П'ять основних психологічних моделей особистості (екстраверсія, дружелюбність, нейротизм, сумлінність, відкритість) визначають сприйняття ступеня серйозності небезпеки, що виникає внаслідок стресу [12].

Окрім підвищеного стресового навантаження, у підлітковому віці змінюється та розвивається індивідуальний адаптаційний потенціал, який визначає поведінкові моделі в дорослому житті та, у свою чергу, впливає на формування фізичного та психічного здоров'я людини. Копінг-стратегії, життєстійкість відіграють значну роль в ефективному подоланні стресових ситуацій. Під стійкістю розуміється риса особистості, що тісно пов'язана 3 навичками пристосованості до тієї чи іншої ситуації та яку характеризує позитивне уявлення про себе, емпатія й оптимізм. Проведені в колі підлітків дослідження Е. Фрайденберга (2008 р.) вказують на те, що особистості, які використовують методи копінгу, які фокусуються на вирішенні проблем, щасливіші та задоволеніші своїм життям, ніж їхні однолітки, які займаються самозвинуваченням та замикаються в собі.

Високий рівень стресу особливо небезпечний у підлітковому віці, зокрема тоді, коли використовуються арсенал дезадаптивних стратегій подолання стресу, що підвищує ймовірність виникнення проблем 3 адаптацією. Водночас дезадаптивні копінг-стратегії можуть мати безпосередній зв'язок із появою таких пагубних звичок, як пристрасть до куріння та вживання алкоголю. Макканн та інші (2012 р.) у своєму дослідженні дійшли висновку, що підвищений рівень стресу знижує рівень задоволеності студентів не лише власним життям, а й навчальним процесом, а також негативно впливає на результати навчання. Наявність очевидного зв'язку між підтримкою однолітків та копінг-стратегіями підтверджується фактом звернення по допомогу або відмови від неї. Своєчасне звернення по допомогу зміцнює процеси пристосування до тієї чи іншої ситуації, тоді як абстинентна поведінка зазвичай ускладнює процес адаптації [13].

Колективне перебування в суспільстві, присутність та підтримка однолітків, а також прив'яза- ність до родинного гнізда та сім'ї є ключовими аспектами в підлітковому віці. Наведені вище дослідження також підтверджують той факт, що раніше пережитий досвід та перебування у відносинах визначають ступінь задоволеності молодих людей власним життям. Насправді ці соціальні ресурси допомагають їм адаптуватися до нових ситуацій [3] і справлятися зі стресом.

Суспільство - це своєрідний безпечний притулок для підлітка: «Сучасне суспільство - це експериментальний простір та місце для реалізації репертуару життєвих ролей особистості. Можливості, що надаються групою, статус у ній можуть запобігти регресивним вирішенням проблем у кризових ситуаціях. У групі однолітків, зважаючи на цінності та норми субкультури, відбувається переоцінка колишніх моделей поведінки та їх співіснування в сучасності. Переживання періоду встановлення особистості можливе лише в суспільстві. Розвиток установлення ідентичності підлітка визначається можливостями, які забезпечує розвинене суспільство для переходу від одного періоду життя до іншого» [9, с. 112].

Людина проживає своє життя в суспільстві і водночас є учасником соціальної формації, де трапляються непередбачувані форми взаємин [11].

Свою увагу фокусуємо на малих групах i фасилітаційних процесах та можливостях, які забезпечуються в цій сфері. Ми погоджуємося 3 думкою Бели Буди, яку він висловив у своєму заключному слові до одного зі своїх досліджень: «Головним інструментом зцілення все ж таки $\epsilon$ група. Насправді саме через існування малих груп людина потрапляе в реальний світ суспільства та стає частиною більш великого колективу. У разі перебування людини в сусідських відносинах вирішально впливає на становлення особистості безпосереднє оточення: це може буде модель сімей, що живуть поруч, колектив на роботі - (неформальне) коло друзів та знайомих, хобі, розваги, спорт тощо, тобто все те, що об'єднує людей у невеликі групи, має вирішальний вплив» [5, с. 182].

Усвідомленість цінностей групи та їі ролі в розвитку особистості прийшла на початку минулого століття. У США Р. Пратт застосував шкільний метод лікування своїх пацієнтів із туберкульозом. На його сеансах зазвичай було від 10 до 20 пацієнтів, динаміка психологічного стану відігравала вирішальну роль у їхньому одужанні [15]. У Відні Дж. Морено створив драматичний гурток для дітей, у Росії А. Макаренко провів реорганізацію педагогічної практики, а в Англії - Ніл. Групова психотерапія почала укорінюватися в Європі та Північній Америці в 1930-х рр., що привело до розвитку системи психодрами Дж. Морено. Саме після Другої світової війни було створено групи 
самосвідомості в сучасному розумінні цього терміна. Спочатку у США, зі зростанням напруженості серед представників різних національностей виникла потреба у створенні програми, яка б допомогла лідерам впоратися із цією проблемою. Льюїн розробив власну програму, яка згодом стала фундаментом функціонування Т-груп, що були створенні з метою розвитку міжособистісних та лідерських навичок.

У $1960-x$ pp., із заснуванням Інституту Есалена в Каліфорнії, а потім Західного інституту поведінкових наук, методи надання допомоги були розширені, до них увійшли невербальні техніки, техніки фантазування та терапія зустрічей. Завдяки роботам А. Маслоу, К. Роджерса, Ф. Перлза, В. Шутца і Баха було започатковано групу зустрічей. К. Роджерс відмовився від назви «Т-група» і натомість просував свою групу самосвідомості під назвою «Основна зустріч» [14]. Натепер існує чимало фасилітаційних жанрів та груп, які покликані допомогти в розвитку учасників згаданої групи.

Щоденний стрес, з яким стикаються студенти, практично неминучий, однак, розробляючи профілактичні програми та надаючи можливості навчитися виробити ефективні стратегії подолання стресу, молоді люди все ж таки можуть уникнути укорінення девіантних форм поведінки. Ураховуючи цю особливість, нашим завданням є запропонувати молодим людям перспективні можливості саморозвитку.

Програми підтримки частково схожі на проєкти «Спільноти самодопомоги», що виконують важливі експресивні функції, створюють площадку, де групове середовище надає можливості особистісного розвитку та позитивної переоцінки ідентичності. Вони також надають можливість практикувати навички, необхідні для участі в житті соціуму, спілкуватися чесно та відкрито, навчитися виявляти емпатію та толерантність, а також отримувати психологічне задоволення від почуття професійної придатності [7].

На чолі гуртків із психічної підтримки, які зазвичай функціонують на базі певної організації, стоїть лідером. Найчастіше це професіонал, який має досвід роботи у сфері надавання психологічної допомоги. Гуртки 3 охорони психічної підтримки мають різноманітні цілі, характерні для інших подібних формувань, однак щодо першого все ж таки переважає психологічна підтримка. Основна мета такої підтримки - надати підтримку під час подолання психологічних проблем із боку людей зі схожими проблемами або таких, які перебувають в аналогічних ситуачіях. I. Ялом серед членів групи підтримки провів опитування, під час якого намагався дізнатися: який вплив, на думку респондентів, має групове середовище на їхнє життя. У результаті опрацювання анкет стало зрозуміло, що найбільшу значущість мають реляційні взаємодії, у рамках яких учасники гуртків відчували важливість вислуховування проблеми інших, отримання допомоги від інших, не почуватися самотніми та відчувати любов і турботу серед своїх одногрупників [2].

Громада, безсумнівно, впливає на формування психічного здоров'я в сучасному суспільстві, а його розвиток - інтерес всіх учасників соціуму [5]. На базі вищого навчального закладу можна ввести в дію низку спеціальних програм підтримки розвитку спільноти, метою яких має стати розроблення програм, що відповідають концепції вищої інстанції з охорони здоров'я. Також важливо шляхом проведення опитування створити базу даних. Основними аспектами такого опитування можуть стати: зарахування до ЗВО, інтеграція, управління стресом, екзаменаційні періоди, сплеск «екзаменаційних неврозів» на різних курcax, проблеми з наркозалежністю, джерела засобів для існування, СЕС, а також профорієнтація та кар'єрна соціалізація.

На кожному курсі у студентів виникають нові потреби. Після їх оцінки можна розробити концепцію усвідомленості щодо здорового способу життя та відповідним чином спланувати процеси інтервенції. Особливо важливим завданням $є$ організація програм охорони психічного здоров'я.

Перш ніж розпочати реалізацію проєкту з охорони психічного здоров'я, доцільно провести оцінку потреб учасників навчального процесу відповідного закладу. Оцінка потреб має проводитись психологом закладу, який водночас є співробітником психологічної служби. Відповідно до виявлених потреб можна розробити подальший план створення гуртка підтримки психічного здоров'я, у рамках якого студенти отримають емоційну підтримку, отже, зможуть керувати своїми відносинами й успішно перенаправляти свою енергію на боротьбу зі стресом і конфліктами.

Гурток підтримки може стати безпечним місцем для студентів, де вони шляхом вираження своїх почуттів можуть знайти потужну та надійну підтримку завдяки тому, що в цьому середовищі вони можуть знайти спосіб сприймати себе, порозумітися один 3 одним, правильно реагувати на сигнали однолітків, трактувати імпульси навколишнього середовища та навчитися справлятися iз труднощами належним чином.

Перед початком запуску нового проєкту в галузі психічного здоров'я рекомендується провести попередній SMART-аналіз (S - Specific, M - Measurable, A - Attainable, R - Relevant/Realistic, T - Timebound) [1] 3 метою уточнення тез, можливостей, потреб і чинників ризику. Нижче наведені результати попереднього SMART-аналізу 
раніше реалізованої групи підтримки психічного здоров'я [4].

Специфіка. Мета - створити закритий гурток на базі Закарпатського угорського інституту імені Ференца Ракоці II, де студенти першого курсу могли б отримати емоційну підтримку, що посприяло б підвищенню їхньої самооцінки, змогли б управляти своїми стосунками й успішно перенаправляти свою енергію на подолання стресу та конфліктів. Особливо важливо відзначити, що гурток, що функціонує на постійній та регулярній основі, може стати першим кроком на шляху до зародження вищого навчального закладу зі сприяння здоров'ю, який функціонуватиме на основі вищеописаної концепції.

Вимірюваність. На кожному груповому занятті ми проводимо опитування щодо задоволеності/ загального самопочуття, не тільки для оцінки поточних почуттів, думок та бажань, але й для оцінки періодизації, прогресу й індивідуального розвитку. Із цієї причини ми вважаємо за доцільне провести тестування на початку і в кінці сеансу. Для цього потрібні такі інструменти: кольорові картки, липкі записки, листівки, картки зі смайликами, різнокольорові брусочки пластиліну, картки iз зображеннями ведмедів.

Ycnix можна констатувати тоді, коли учасники гуртка «витримають» заняття до кінця і відвідуватимуть їх регулярно, не пропусктимуть жодної зустрічі. Проявляють активність на заняттях, говорять про свої почуття, відкрито висловлюють свою думку та беруть участь у навчальних іграх. Найяскравішим доказом ефективності групових занять могло б стати те, якби зміни були помітні в повсякденному студентському житті, тобто у студентів спостерігалося б підвищення стресостійкості під час іспитів та знизився б відсоток відсіву.

Про недоцільність можна говорити тоді, коли студенти не взагалі виявляють бажання брати участь у новому проєкті, не відвідують заняття, не дискутують на обрані для занять теми, 3 недовірою ставляться один до одного, стиль спілкування один з одним ніяк не змінюється.

Проєкт уважається визнаним, коли його план ідеально вписується в річний план інституту. Заняття групи підтримки «Ментальне гніздо» будуватимуться таким чином, що вони починаються за півгодини після закінчення навчального дня, після 5-ї пари щотижня. Окрім групових занять, доцільно було б організувати індивідуальні сеанси психологічної підтримки, які проводилися б у спеціально відведеному приміщенні.

Про реалізованість проєкту на базі інституту на найвищому рівні може йтися за умови добре заздалегідь спланованих кроків, ретельної організації й управління часом.
Періодичність. Групові заняття проводяться щотижня. Попередньо планується відкрити дві групи на семестр, 3 можливістю розширення до трьох груп, якщо це необхідно. Програма початкового проєкту розрахована на шість - сім занять, а 3 урахуванням набутого досвіду та конкретних потреб кількість груп може бути збільшена [4].

Ресурсами для реалізації програми психічного здоров'я завжди стають насамперед учасники команди, які виконують роль інтелектуальних ресурсів, однак проведення занять із психічного здоров'я неможливе без фінансових ресурсів та підтримки. До проведення занять варто залучити колег-викладачів, які раніше вже закінчили курси із психосоціальної допомоги. Важливо підкреслити, що на групових заняттях постійна присутність психолога є обов'язковою.

До наведених вище суджень можна додати й те, що інтелектуальні ресурси забезпечують надійну підтримку для безперебійної організаційної роботи. Професійні навички, досвід та творчий підхід членів команди, що беруть участь у реалізації проєкту, мають першорядне значення. «Привнесені цінності» студентів-учасників відіграли вирішальну роль у формуванні спільноти та навчили нас, окрім іншого, завзятості та терпіння.

У будь-якому разі під час розроблення плану занять варто враховувати наявні фінансові ресурси. Досвід вказує на те, що проєкт можна втілити в життя за наявності мінімальних ресурсів (аудиторія, ноутбук, проєктор, аркуші паперу, кольорові олівці), які є в розпорядженні установи, на базі якої реалізовується проєкт.

Для реалізації проєкту з охорони психічного здоров'я ми можемо використовувати методи, які набувають значення через зіставлення потреб. Наприклад, причиною проведення регулярних щотижневих зустрічей і групових занять можуть послугувати такі потреби: виконання вправ на розвиток групової динаміки 3 дотриманням педагогічно-дидактичних засад процесу навчання; демонстрація фільмів із подальшим обговоренням побаченого в рамках групової форми роботи; виконання вправ на подолання комунікативних бар'єрів, управління стресом та конфліктами; метод проєктного аналізу малюнків, у якому використовуються можливості психологічної інтервенції.

Важливо документувати етапи проєкту, а саме датувати та записувати в щоденник усі, навіть незначні події, які трапилися під час проведення занять. До особливо важливих деталей можна віднести саморефлексію, аналіз та пропозиції, які з'являються під впливом якоїсь події. Досвід, отриманий на груповому занятті, може послугувати поштовхом для набору наступної групи. Основою для остаточних висновків слугує досвід, отриманий на останньому груповому занятті, 
та результати аналізу ефективності проєкту. Окрім того, проведення регулярної аналітичної роботи дозволить адаптувати наступні заняття під потреби учасників групи, а також правильно розпочати роботу із другою групою. На основі записів, що вносяться у щоденник, можна відстежити настання можливих змін та зрозуміти причину ïх наявності чи відсутності. Головне завдання команди полягає у спостереженні за індивідуальним прогресом та наданні інших додаткових консультацій у разі необхідності.

Висновки. Існує безліч можливостей для організації різноманітних профілактичних програм, які дають шанс навчитися виробляти ефективні стратегії подолання труднощів і цим уникнути укорінення шкідливих форм поведінки серед молоді. Передусім дослідження фокусується на компо- ненті, який характеризує здатність спільноти до утримання молоді в тому чи іншому середовищі. Люди - істоти соціальні, оскільки суспільство $\epsilon$ безпечним притулком для підлітків, ми маємо запропонувати нашим молодим людям можливості для пошуку нових перспектив. Гурток 3 охорони психічного здоров'я, що функціонує на базі вищого навчального закладу, - насамперед місце, орієнтоване на надання взаємодопомоги та підтримки з боку людей зі схожими проблемами або з боку тих, які перебувають в аналогічних сumyauiяx, під час подолання психологічних проблем. Запуск проєкту з охорони психічного здоров'я у вищому навчальному закладі - це новаторська ініціатива, основною метою якої є підвищення обізнаності щодо важливості збереження психічного здоров’я всіх учасників навчального процесу.

\section{ЛІТЕРАТУРА}

1. Asztalos B., Járay M., Szentjóbi O. Álom, terv, tett. Gyakorlati útmutató és példatár mentálhigiénés projektekhez. Budapest : Antropos Mentálhygiénés Egyesület, 2017. 302 o.

2. Barcy M. Segítő módszerek, fejlesztő-támogató eljárások. Budapest, 2012. 206 o.

3. Berghauer-Olasz E. A kinetikus iskolarajz mint közösségek rejtett kapcsolatainak feltáró módszere. Doktori (PhD) értekezés., Pécs : PTE BTK Pszichológia Doktori Iskola, 2016. 237 o.

4. Berghauer-Olasz E. A közösség szerepe a lelki egészség megőrzésében. A Mentál Fészek föiskolai mentálhigiénés támogató csoport. Szakdolgozat. Károli Gáspár Református Egyetem, Pszichológiai Intézet, Mentálhigiénés Segítő Szakirányú Továbbképzési Szak. Budapest, 2017. 71 o.

5. Buda Béla. Mentálhigiéné. Budapest : Animula Kiadó, 1994. 312 o.

6. Carver C.S., Scheier M.F. Személyiségpszichológia. Budapest : Osiris Kiadó, 2006. 590 o.

7. Csepeli Gy. Szociálpszichológia. Budapest : Osiris Kiadó, 2005. 571 oldal.

8. Dúll A. A környezetpszichológia alapkérdései. Helyek, tárgyak, viselkedés. L’Harmattan. Budapest, 2009. 372 o.

9. Frenkl S., Rajnik M. Életesemények a fejlődéslélektan tükrében. Budapest : Párbeszéd (Dialógus) Alapítvány, 2011. 160 o.

10. Horvát M.T. Költözés és honvágy diákkorban. Fiatalok biztonságkeresési stratégiái az információs társadalomban. Primaware Kiadó / J. Körössy, Z. Kőváry (szerk.). Szeged, 2012. P. 62-78. 208 o.

11. Mérei F. Közösségek rejtett hálózata. Budapest : Tömegkommunikációs Kutatóközpont, 1988. 328 o.

12. Oláh A. Megküzdés és pszichológiai immunitás. Bevezetés a pszichológiába / Pléh Csaba, Boross Otília (szerk.). Budapest : Osiris Kiadó, 2004. P. 632-663. 920 o.

13. Pikó B., Hamvai Cs. Stressz, coping és reziliencia korai serdülökorban. Iskolakultúra. 2012. 9. sz. P. 24-33. 108 o.

14. Rudas J. Önismereti csoportok.. Budapest : Animula Kiadó, 2001. 192 o.

15. Szilágyi I. Önismeret és személyiségfejlesztés. Budapest : Skandi-Wald Kiadó, 2004. 72 o.

\section{REFERENCES}

1. Astalosh V., Jaroi V., Sentiovbi O. (2017). Mriia, plan, diia. Posybnik ta zbirnyk prykladiv dlia praktichnikh proektiv z psykhichnoho zdorovia [Dream, plan, action. A study guide and a praxis for practical projects in mental hygiene]. Budapest : Orhanizaciia psykhichnoho zdorovia Antropos [The Antropos Mental Hygiene Association] [in Hungarian].

2. Bartsi M. (2012). Metody dopomohy, protsesy rozvytku ta pidtrymky [Assistive methods, developing and supportive procedures]. Budapest [in Hungarian].

3. Berhkhauer-Olas E. (2016). Kinetychnyi maliunok skoly iak mozhlyvyi metod analyze sotsialnykh zviazkiv. Doktorska (PhD) dysertatsiia. Universytet Pech (Uhorschyna), Instytut Psycholohii, Doktorska Skola Psycholohii. Pech. [Kinetic school drawing as a method of revealing hidden social relationships. Doctoral (PhD) dissertation. University of Pécs, Institute of Psychology, Doctoral School is Psychology] [in Hungarian].

4. Berhkhauer-Olas E. (2017). Rol spilnoty u pidtrymtsi psykhichnoho zdorovia. Hrupa pidtrymky psykhichnoii hihieny instytutu "Mentál Fészek". [Kinetic school drawing as a method of revealing hidden social 
relationships. Doctoral $(\mathrm{PhD})$ dissertation. University of Pécs, Institute of Psychology, Doctoral School is Psychology] [in Hungarian].

5. Buda B. (1994). Psykhichne zdorovia [Mental Hygiene]. Budapest : Animula [in Hungarian].

6. Carver C., Scheier M. (2006). Psykholohiia osobystosti [Personality psychology]. Budapest: Osiris [in Hungarian].

7. Csepeli D. (2005). Sotsialna psykholohiia [Social psychology]. Budapest : Osiris. [in Hungarian].

8. Dull A. (2009). Osnovni pytannia ekolohichnoi psykholohii. Mistsa, predmety, povedinka [Basic issues of environmental psychology. Places, objects, behavior]. Budapest : L'Harmattan. [in Hungarian].

9. Frenkl, S., Rajnik M. (2011). Zhyttevi podii na tli psykholohii rozvytku [Life events in the light of environmental psychology]. Budapest: Foundation Dialogue [in Hungarian].

10. Horvat M. (2012). Pereizd ta tuha za domom v studentskomu vici. Dzherelo: Kereshi J., Kevari Z. Stratehii poshuku bezpeky molodiu $\mathrm{v}$ informatsiinomy seredovyschi. [Moving away and homesickness of students. In: Körössy, J. - Köváry, Z. (edit.) Safe searching strategies of the youth in the informational environment]. Szeged : Primaware. [in Hungarian].

11. Mérei, F. (1988). Prykhovana merezha spilnot. [The hidden network of communities]. Budapest: Mass Communication Research Centre. [in Hungarian].

12. Oláh A. (2004). Borotba ta psykholohichnii imunitet. [Coping and psychological immunity]. In: Pléh Cs., Boross O. (edit.) Vstup u psikholohiu [Introduction to psychology]. Budapest : Osiris [in Hungarian].

13. Pikó, B., Hamvai, Cs. (2012). Stres, borotba na psykholohichna rezylentnist u rannomu pidlitkovomu vici. Dzherelo: Shkilna kultura. [Stress, coping and resilience in the early adolescence. In: Iskolakultúra. [School culture] № 9. pp. 24-33. 108 p.

14. Rudas, J. (edit.) (2001). Hrupy samopiznanna. [Self-awareness groups]. Budapest: Animula [in Hungarian].

15. Szilágyi, I. (2004). Samopiznanna ta rozvytok osobystosti [Self-awareness and personality development]. Budapest : Skandi-Wald [in Hungarian]. 